\title{
e-Learning Challenges Faced by Universities in Kenya: A Literature Review
}

\author{
Rachael Njeri Kibuku ${ }^{1}$, Prof. Daniel Orwa Ochieng ${ }^{2}$ and Prof. Agnes Nduku Wausi ${ }^{2}$ \\ ${ }^{1}$ KCA University, Faculty of Computing and Information Management, Nairobi, Kenya \\ ${ }^{2}$ University of Nairobi, School of Computing and Informatics, Nairobi, Kenya \\ jikibuku@gmail.com, rkibuku@kca.ac.ke \\ dorwa@uonbi.ac.ke \\ wausi@uonbi.ac.ke \\ DOI: 10.34190/EJEL.20.18.2.004
}

\begin{abstract}
Some institutions of higher education in Kenya have adopted e-Learning with the aim of coping with the increased demand for university education and to widen access to university training and education. Though there are advantages that accrue from adopting e-Learning; its implementation and provision has not been smooth sailing. It has had to contend with certain national, organisational, technical and social challenges that undermine its successful implementation. This paper therefore aims to present a literature review of the challenges faced in the implementation and provision of e-Learning in universities in Kenya. The scoping review method was used to identify and analyze the literature of the e-Learning challenges. Some of the challenges revealed include: lack of adequate e-Learning policies, inadequate Information and Communication Technology (ICT) infrastructure, the ever evolving technologies, lack of technical and pedagogical competencies and training for e-tutors and e-learners, lack of an e-Learning theory to underpin the e-Learning practice, budgetary constraints and sustainability issues, negative perceptions towards e-Learning, quality issues, domination of e-Learning aims by technology and market forces and lack of collaboration among the e-Learning participants. These challenges need to be addressed to minimise their impact on implementation and delivery of eLearning initiatives in institutions of higher education in Kenya. This analysis of the e-Learning challenges forms the basis for the ongoing research that seeks to explore and establish possible strategies to address some of these challenges.
\end{abstract}

Keywords: ICT, Distance Education (DE), e-Learning, e-Learning Challenges and Kenya

\section{Introduction}

In the last 20 years or so, more than ever before, we have witnessed a high demand for university education in Kenya which was necessitated by the increased number of high school graduates and working class students (Nyerere, Gravenir and Mse, 2012). This demand has in turn led to an increased number of universities and middle level colleges. According to the Commission of University Education (CUE) by November 2017 there were 31 state sponsored universities with six constituent colleges, 18 private sponsored universities with five constituent colleges, and 14 universities functioning with letters of interim authority (CUE, 2017). However, even with this increased number of institutions of higher education it is still not enough to cater for the increased demand for education. This is because Kenyan institutions of higher education have not expanded at the same rate to match this demand hence further widening the educational access gap. Some universities in Kenya have therefore embraced e-Learning with a view to bridge this gap while at the same time improve learning flexibility especially for the employed learners. Eight state sponsored and five private sponsored universities have e-Learning programs (Nyerere, 2016).

The Kenyan universities' e-Learning departments grew through the various key developmental generations to having well tested and running e-Learning platforms (Wambugu and Kyalo, 2013). University of Nairobi (UoN) pioneered Distance Education (DE) in Kenya in the 1960s, with its teacher training correspondence programme. This programme was supplemented by regional and on-campus face-to-face tutorials coupled with seminars. Learner-tutor interactions included [and still do] brief meetings for induction, counseling, tutelage and learning at the learner support centres (formally known as extra-mural centres) which were [and still are] located in Nairobi, Nakuru, Nyeri, Kisumu, Mombasa, Kakamega, Kisii, and Garissa. Under the supervision of these learner support centres, weekend sessions were [and still are] organised to take place one day per month in selected teacher training colleges or high schools with amenities such as classroom, laboratories and libraries (Wambugu and Kyalo, 2013). By 2004, the UoN had developed its own Learning Management System (LMS) christened the Wedusoft (Omwenga and Rodrigues, 2006; Ssekakubo, Suleman and Marsden, 2011). The university then adopted and implemented the Chisimba LMS in collaboration with their development partners before moving to Claroline LMS (Ssekakubo, Suleman and Marsden, 2011). 
Kenyatta University (KU) is another institution that has a mature e-Learning department which was recently rebranded "digital school". KU follows the same model of e-Learning and has support centres in many parts of the country offering the same services as the UoN (Nyerere, Gravenir and Mse, 2012).

\section{Research Problem}

e-Learning has many benefits that include: widening access to the reach of many learners in a flexible manner, improving the effectiveness of learning and teaching via technology, increasing efficiency in e-Learning administration, reducing public spending in education and training, and increasing quality of research among others (Arkorful and Abaidoo, 2014). However, despite the numerous e-Learning benefits, promises and opportunities, e-Learning initiatives in institutions of higher education in Kenya are faced by a number of challenges that leave the stakeholders dissatisfied when they fail to meet their expectations. According to Wright, Dhanarajan and Reju (2009) and Ssekakubo, Suleiman and Marsden (2011), most of the e-Learning projects in third world countries either fail partly or wholly thus failing to deliver on their promise. Nyerere, Gravenir and Mse (2012) revealed that most of the e-learners (90.8\%) were dissatisfied with the delivery of eLearning and $85.6 \%$ of the e-tutors indicated that they were demotivated in executing their e-Learning responsibilities. These drawbacks in turn have led to a slow uptake of e-Learning in institutions of higher education in Kenya (Nyerere, 2016). This literature review therefore seeks to unearth the key challenges that are hindering the delivery of e-Learning in the Kenyan context.

\section{Literature Review Method}

This review employed the scoping review method; which is a broad and comprehensive approach to reviewing literature that quickly matches the main variables and key terms behind the review to the key sources of the literature (Dijkers, 2015). The review sought to compare and integrate findings from past studies using content analysis with the aim of identifying the major themes or constructs running across the available body of literature (Booth, Papaioannou and Sutton, 2012). The identified materials were then synthesised and a thematic narrative of the findings was made. According to Stepanyan, Littlejohn and Margaryan (2013) scoping review is useful in studying trends in a contemporary area such as e-Learning where concepts are still evolving. The reviewed papers were obtained from Google Scholar using the English language. Some other materials specific to the Kenyan context were obtained from specific websites. The search was restricted by use of the key terms presented in the Table 1 in conjunction with "AND" to identify materials published between the year 2000 and 2019. Though the queries returned a huge amount of papers and materials we narrowed the focus to the specific e-Learning challenges experienced in the Kenyan context. Some materials were discarded in favour of more current publications as well as on the basis of content and context relevance. In total 48 documents were reviewed as shown in Appendix I. The review followed the steps of the scoping review approach as stipulated by Arksey and O'Malley (2005) and summarised the results of every step as shown in Table 1 below. 
Table 1: Scoping Review Steps, Activities and Outcomes

\begin{tabular}{|c|c|c|}
\hline & Step/Activities & Outcomes \\
\hline & $\begin{array}{l}\text { Identify research } \\
\text { question(s) }\end{array}$ & $\begin{array}{l}\text { What are the challenges faced by universities, e-learners and e-tutors in the implementation } \\
\text { and delivery of e-Learning in Kenya? }\end{array}$ \\
\hline 2. & $\begin{array}{l}\text { Identify key terms } \\
\text { and use them to find } \\
\text { pertinent studies }\end{array}$ & $\begin{array}{l}\text { The following are the strings of key terms used for the primary search of materials. } \\
\text { 1. e-Learning opportunities and challenges } \\
\text { 2. e-Learning successes and failures } \\
\text { 3. e-Learning advantages and disadvantages } \\
\text { 4. } \\
\text { 5. } \text {-Learning benefits and challenges } \\
\text { 6. e-Learning in Kenya } \\
\text { 7. e-Learning challenges in Kenya } \\
\text { A secondary search was done depending on the results of the primary search and the } \\
\text { following were the key term used. } \\
\text { 1. e-Learning pedagogical issues in Kenya } \\
\text { 2. e-Learning theoretical issues } \\
\text { 3. ICT and e-Learning policy framework in Kenya } \\
\text { 4. Interactive and collaborative e-Learning in Kenya } \\
\text { 5. ICT infrastructure and key services in Kenya } \\
\text { 6. Quality Assurance in e-Learning in Kenya } \\
\text { 7. } \\
\text { Technology issues in e-Learning in Kenya }\end{array}$ \\
\hline & $\begin{array}{l}\text { Select the related } \\
\text { studies }\end{array}$ & $\begin{array}{l}\text { The literature review was conducted from a total } 47 \text { documents. The following is the } \\
\text { breakdown: - } \\
\text { 1. } 28 \text { Journal articles } \\
\text { 2. } 13 \text { Official publications } \\
\text { 3. Four conference papers } \\
\text { 4. Two books } \\
\text { 5. One book chapter } \\
\text { NB: An extra four journal articles were used to inform the scoping review approach. }\end{array}$ \\
\hline 1. & $\begin{array}{l}\text { Extract the major } \\
\text { themes and } \\
\text { constructs }\end{array}$ & $\begin{array}{l}\text { The major themes that were running throughout the available literature include: - } \\
\text { 1. There are some opportunities and benefits that accrue from e-Learning and hence the } \\
\text { impetus for its adoption. } \\
\text { 2. There are specific challenges that face e-Learning in Kenyan universities context. }\end{array}$ \\
\hline 2. & $\begin{array}{l}\text { Integrate, } \\
\text { summarise and } \\
\text { report the findings }\end{array}$ & $\begin{array}{l}\text { The study integrated and summarised the finding in step } 4 \text { and made a narrative report that is } \\
\text { presented in this paper }\end{array}$ \\
\hline
\end{tabular}

\section{Results and Discussion}

This section presents the major challenge categories that are recurrent in the implementation and delivery of e-Learning in universities in Kenya as found from the literature.

\subsection{ICT and e-Learning Policy Implementation Issues}

Policy frameworks play a crucial role in guiding the implementation and provision of e-Learning (Nyerere, 2016). The presence or absence of such a framework determines whether or not e-Learning initiatives will fail or succeed. In the Kenyan context the initial government policy that dealt with DE in institutions of higher education was anchored on the Act of Parliament of 1966, that created the Adult Education Board. Over time, many other educational commissions and reports have underscored DE and e-Learning as a substitute method of delivering education (Farrell, 2007). The Sessional Paper No. 1 of 2005 contained another government policy initiative, which suggested the creation of a National Open University [not yet established] and the use of eLearning to develop human resource capacity (Republic of Kenya, 2005). Similarly, the Government of Kenya Sessional Paper of June 2012 on Policy Framework for Education and Training also admitted that; although the Sessional Paper No. 1 of 2005 mentioned an e-Learning policy; such a policy framework was still absent seven years later. However, the 2012 Sessional Paper drew up an e-Learning policy framework to guide the practice in the country from the year 2012 going forward; though these guidelines have largely remained unimplemented at the national level to date.

The National ICT Policy of 2006 that had guided ICT implementation in Kenya for 10 years, was inadequate to address the e-Learning practice, since in itself it lacked a strategy on e-Learning. This inadequacy was later addressed in the National ICT Policy of 2016 which saw the inclusion of an elaborate section on e-Learning policy strategies. One such strategy states that the government will establish educational databases for sharing learning and teaching resources. The policy also advocated for e-Learning inclusion at all levels of education with the aim of increasing the quality of learning and training. It further stated that the government will advocate e-Learning and virtual campuses implementation particularly in universities and colleges. The policy also included other related strategies that are meant to promote the growth and expansion of e-Learning 
capacity. Such strategies included expediting the public and private partnerships (PPP) with the aim of marshalling resources needed to fund e-Learning implementations and the designing of a unified e-Learning curriculum that will back the use of ICTs in learning and teaching.

However, even with these e-Learning strategies in the new National ICT Policy of 2016, we still don't have a clearly defined national e-Learning policy framework to guide the practice. In the absence of a national eLearning guiding policy the practice in Kenya had been driven by individual organisation's policies. A study by Nyerere (2016) entitled "Open and Distance Learning in Kenya" showed that 11 out of the 12 universities surveyed have e-Learning policies; however, the problem is in operationalisation of these organisational policies in the absence of a national policy framework for e-Learning. The importance of national e-Learning policy is to offer a shared framework for the design, deployment and delivery of e-Learning in which individual organisations can base their organisational policies. It would also be instrumental in e-Learning resource deployment and quality assurance. Research by Tarus, Gichoya and Muumbo (2015), reported that the absence of operational e-Learning policies was a key impediment to the effective deployment of e-Learning in some of the Kenyan state sponsored universities. Furthermore, the study observed that, although some institutions had e-Learning policies they were unable to implement them due to financial limitations and lack of the relevant ICT infrastructure. In some universities the e-Learning policies were still in the draft version for years without being operationalised.

\subsection{Lack of and/or Inadequate ICT Infrastructure}

The Government of Kenya Sessional Paper of June 2012 on Policy Framework for Education and Training recognised ICTs as the main conduit for e-Learning. The delivery of e-Learning depends on a flourishing ICT infrastructure which is far from satisfactory in Kenya. The country is characterised by a large digital divide between the urban and rural areas when it comes to key ICT infrastructure and internet access which averages to 69\% (Ndungu, Lewis and Mothobi, 2019). The Kenya Digital Economy Blueprint, 2019 report also observed this divide reporting that there are 580 sub-locations in Kenya with below 50\% GSM (Global System for Mobile communication) coverage while about 160 sub-locations do not have a mobile signal whatsoever. It further says that there are about 2,000 sub-locations with below $50 \% 3 \mathrm{G}$ network coverage, half of which are out of reach of the $3 \mathrm{G}$ services completely. Moreover, it goes on to say, that broadband network services cover a small geographical area equivalent to $17 \%$ of the landmass leaving $83 \%$ of the country without broadband coverage. The same was noted for the fibre optic cables that equally has a landmass coverage of $17 \%$. However, the report observed that the digital divide has been diminishing, albeit very slowly. Earlier on Nyerere (2016) reported that universities in key urban areas had good ICT infrastructure; for example, University of Nairobi, United States International University, Jomo Kenyatta University of Agriculture and Technology, Nazarene University of Africa, St Paul's University, Kenyatta University, among others. While universities in suburban or medium sized towns such as Maseno University, Karatina University and Egerton University had moderate ICT infrastructure and universities in rural settings such as Moi University, Garrissa University and Masinde Muliro University of Science and Technology among others had low ICT infrastructure.

This digital divide has been slowly diminishing with public and private sector initiatives such as the laying of the fibre optic infrastructure that has increased Internet bandwidth causing faster communications and enhanced use of e-Learning (Communication Authority of Kenya, 2018). Further, since ICTs are powered by electricity; the rural electrification programme (REP) and the last mile electricity connectivity initiative are other government effort geared towards the expansion of the national ICT infrastructure. For example, by the end July 2015, the government was seeking to connect 314,200 non-commercial customers, primary and secondary schools on the national power grid during the first phase of the programme (Kenya Power and Lighting Company, 2017). The number of connections under the REP increased from 1,269,500 customers in 2016/17 financial year to 1,332,100 customers in 2017/18 financial year (Kenya National Bureau of Statistics Economic Survey, 2019, p.160). Internet Service Providers'(ISPs) penetration in the country is another consideration to make when reviewing the country's ICT infrastructure; the July-September quarterly Communication Authority's report of the 2018/19 financial year entitled "Public Sector ICT Survey Report"; indicated an increase in mobile phone subscription to 46.6 million users up from 45.5 million users in the previous year. This growth was attributed to the market expansion by the ISPS as well as availability of affordable mobile phones. In the same period the report indicated that mobile data [Internet] subscription stood at 42.2 million users, an increase from 41.1 million users in the previous year. This increase was attributed to the continued fall of smartphone prices (Communications Authority of Kenya, 2018). However, even with these initiatives, the coverage and accessibility of ICT infrastructure and services in the country is 
still not satisfactory and there is need to bridge the digital divide further in the wake the geographical and economic disparities observed so far in the deployment of ICT infrastructure in the country (Awour and Kaburu, 2014; Mutisya and Makokha, 2016; Ndungu, Lewis and Mothobi, 2019).

At the institutional level some universities are characterised by low levels of ICT and e-Learning infrastructure as a result of the high costs associated with acquiring, implementing and sustaining the ICT infrastructures needed for the provision of a thriving e-Learning environment (Nyerere, 2016). This in turn limits access to eLearning since the available ICT infrastructure is not scalable to accommodate the ever-growing number of elearners seeking university education as well as to accommodate the high number of ICT resources needed (Sabi, 2014). Kashorda and Waema (2014) in their study entitled "E-Readiness Survey of Kenyan Universities" conducted in 30 universities, found out that there was a low ratio of personal computers (PC) to students. The study reported that there were only 16,174 computers in the laboratories to serve a population of 423,664 students enrolled in those universities. Though this challenge inhibits access to e-Learning; the same study however observed that it was compensated [though not eliminated] by the large number of students $(200,000$ $=53 \%$ ) who owned laptops. The same study argued that the internet is needed for a vibrant e-Learning environment, which was measured by use of two indicators: availability and affordability. Their study therefore recommended that individual institutions should take up the responsibility to draw up policy strategies to increase Internet access to the increased learner enrolment rates, in order to take advantage of the efforts by the Kenyan government aimed at continuously improving the ICT regulatory framework. The study also recommended that, because the universities are already connected to the national fibre backbone network, they should adequately invest in local area networks (LANs) and Wireless LANs to allow learners connect their mobile devices and access learning services (Kashorda and Waema, 2014).

\subsection{Lack of ICT and Pedagogical Skills/Training on the Part of e-Tutors and e-Learners}

The Government of Kenya Sessional Paper of June 2012 on Policy Framework for Education and Training noted that there is inadequate ICT capacity for e-tutors which is a challenge to the delivery of e-Learning. To address this challenge, the sessional paper proposed the following policy actions: compulsory ICT training for all teachers and education managers by 2015, ensuring ICT competencies are acquired by all pre-service teacher trainees, continuous training of teachers to maintain the ICT competencies and developing and implementing ICT Education and Training Strategic Plan. Unfortunately, as noted earlier; the policy strategies and recommendations of this sessional paper largely have remained unimplemented.

With respect to the specific institutions, there were two aspects to capacity building: technical training and pedagogical training. The National ICT Policy (2016) also recognised the need to develop the capacity of various institutions providing ICT related training with the aim of increasing trained personnel and improving the quality of their technical skills. Nyerere, Gravenir and Mse (2012) and Tarus, Gichoya and Muumbo (2015) in their respective studies also reported the lack of e-Learning technical competencies as well as the e-content creation skills on the part of the e-tutors as a key hindrance to the enactment of e-Learning in state sponsored universities in Kenya. They further observed that even where there is training on the part of e-tutors, the focus is on the technical functionalities of the system as opposed to the e-Learning pedagogical training which is the real challenge. However, Isaacs \& Hollow (2012) in their e-Learning Africa (2012) Report; argued that there is a pessimism and an aversion encapsulated in Kenyan e-tutors that ICTs will replace them in their jobs. Thus, ICT training and integration of ICTs in provision of education has been misunderstood by some e-tutors as opposed to arousing the desired interest. Elsewhere Tarus and Gichoya (2015), emphasised the need for the elearners to also be inducted and trained in ICT and e-Learning skills in order for them to learn in this entirely new setting.

Finally, in the 2013 E-Readiness Survey of Kenyan Universities the ICT human capacity showed a slight improvement from stage 2.9 in the 2008 survey to stage 3.0 (Kashorda and Waema, 2014). This is one stage below the highest achievable stage of 4.0 which means there is room for improvement on e-tutor ICT skills and training.

\subsection{Financial Constraints and Sustainability Issues}

Manro, Sighn and Joshi (2012) and Sabi (2014) in their respective e-Learning studies noted that costs are a major challenge in implementing and delivering e-Learning in third world countries. They observed that the implementation and sustainability costs for a dependable ICT infrastructure is very high for many universities in the developing countries [Kenya included] causing them to trail the developed countries when it comes to 
technological developments. On the other hand, Kashorda and Waema (2014) argued that a high degree of ICT implementation and use enhances learning, teaching and research. It also supports universities in achieving their academic and managerial objectives. Nonetheless, a higher level of ICT implementation implies increased costs for universities which mainly work under tight financial constraints. Tarus, Gichoya and Muumbo (2015) also reported that many state sponsored universities find themselves constrained by financial resources, which sometimes, among other reasons, causes e-Learning not be prioritised in their budgets as a main investment.

According to a study of e-Learning practitioners in Africa, it was reported that among the immediate priorities for action was funding (Hollow, 2009). Some cost impediments reported were: initial, maintenance, training, econtent development and bandwidth costs. Complicating the issue of cost further is the ever-changing technological innovations and their varying costs, thus making it difficult for the institutions to keep up with these changes. However, according to the e-Learning Africa (2012) Report it is worth to note that bandwidth costs have been reducing since the laying of the undersea fibre optic cable in Kenya and with the new ISPS joining the market. However, while this may be true for some institutions; the bandwidth costs remain significantly high for some institutions.

\section{5 e-Learning Quality Issues and Negative Attitudes Towards e-Learning}

Quality is seen as the degree of excellence and in the e-Learning context Njoroge and Kibaru (2012) viewed it as the outstanding, excellent, valuable and positively impactful service to the e-learner. According to Gaskell and Mills (2014) the quality of e-Learning delivery has at times been challenged and questioned; where elearners and e-tutors have had to contend with negative perceptions from their conventional learning counterparts and prospective employers regarding the general quality of the e-Learning programs undertaken as well as qualifications achieved. Njoroge and Kibaru (2012) noted that e-Learning quality in Kenyan Universities is hard to measure because it has many stakeholders each with conflicting interests; who range from; e-learners, e-tutors, institutions, CUE, the government and the employers. The other challenge with quality is that it is evaluated against the e-Learning technologies, courses and programmes as opposed to the inputs, processes and educational objectives. As observed earlier; e-Learning benchmarking remains a key challenge in universities in Kenya in the absence of adequate guiding national e-Learning policy. Thus the matter of e-Learning benchmarks and standards was left to the individual universities. Previously the state sponsored universities were autonomous and hence they defined their own standards for operation. The private sponsored universities were regulated by the then Commission for Higher Education (CHE) whose mandate ceased with the enactment of the Universities Act 2012 which brought both the state and private sponsored universities under the regulation of CUE in 2013 (Republic of Kenya, 2016). Even with CUE in charge, there still lacks a comprehensive national quality assurance (QA) strategy to drive the e-Learning agenda. Besides, the inadequate QA policies are not specific to e-Learning but are more generally applicable to conventional learning programs (Nyerere, 2016). Further, Hadullo, Oboko and Omwenga (2017) pointed out that although there are e-Learning models and frameworks for assessing e-Learning quality, some of them work well in the developed world as opposed to the Kenyan context and hence the need for customised quality framework.

\subsection{Domination of Educational Aims and Goals by Technology}

e-Learning has been argued to be technology-led, a fact that has led to the observable trend whereby institutions overemphasise the technologies used to deliver e-Learning as opposed to the learning process and outcomes. Such an ideology of e-Learning is described as techno-positivist by Njenga and Fourie (2010). It is the compulsive enthusiasm and euphoria about the possible promises, benefits and opportunities that eLearning purports to deliver, while disregarding the concerns of the intended users and the negative impacts of technology on users. It also ignores the current research findings about e-Learning use and the associated inventions. This techno-positivist ideology denies the e-Learning practitioners and researchers alike the opportunity to interrogate the intentions, capabilities, advantages and constraints of ICTs. It also denies them the opportunity to study and assess the implications of these new technologies on the e-pedagogy. This ideology is mainly propagated by technology vendors (Shank, 2015) and sold to education administrators with a view to increase the sales of their technologies. This in turn leads to the domination of educational aims and institutional development strategies by technology and market forces; thus forcing the attention in e-Learning to be on the ' $\mathrm{e}$ ' as opposed to the 'learning'. Technologies by themselves cannot improve learning but appropriate choice of such technologies and how they are used is what changes the learning process. This is perhaps better captured by Cuban (2001) in his book "Oversold and Underused Computers", where he argues 
that many universities in the 1990s [to date] acquired new technologies and fitted them in old universities for which the tutors and learners did not use to deliver on educational aims and goals.

This problem is replicated in universities found in the third world countries; where most of the e-Learning technologies in use have been borrowed from the developed countries. These technologies were designed following the needs and requirements based on developed countries' contexts which are clearly very different from the third world's contexts. Trying to fit these borrowed technologies to universities in the third world contexts causes further challenges. This borrowing has been necessitated to a certain extent by the high financial resources and ICT infrastructural requirements needed to run top e-Learning solutions; which remain elusive to many universities in third world countries as observed earlier. Thus institutions do not develop their own e-Learning platforms but instead use open source software for which they don't have to pay license fees (Ssekakubo, Suleman and Marsden, 2011). The commonly used e-Learning software in Kenya include Moodle, WebCT (Web Case Tools) and Blackboard. Njenga and Fourie (2010) advised that prior to investing in eLearning, universities should undertake their own feasibility studies to establish how their e-Learning technological choices will further their academic objectives in respect to their intended users while at the same time maintaining their competitive advantage.

\subsection{Lack of Adequate e-Learner Support and Collaboration}

Khetan and Gupta (2013) observed that learners learn more effectively and efficiently by taking part in the learning process, interacting amongst themselves, discovering ideas and facts on their own and by experiencing knowledge firsthand. However, this is not the case with most present-day e-Learning systems; since they are content-centred and they fail to offer an individualised learning context based on learners' cognitive capabilities and interests. They further argued that, the most outstanding common characteristic of many e-Learning systems is that they encourage an inert e-learner; a fact attributed to the lack of synchronous interactive capabilities that are the trademark of learner-tutor and learner-learner interaction.

Further, Wu, Tennyson and Hsia (2010) observed that many e-Learning environments lack campus-based interaction and flexible tutorial support leading to learner isolation, frustration, confusion as well as low enthusiasm on the subject matter. Muuro, et al. (2014) also found out that many e-Learning initiatives in Kenya are characterised by lack of e-tutor's feedback, learner collaboration and campus social context. Their study further found out that e-tutors failed to initiate collaborative activities among the e-learners with $41.3 \%$ of e-learner respondents citing that their e-tutors did not engage them in collaborative tasks. In situations where the e-learners were engaged in collaborative activities $47 \%$ cited lack of e-tutor feedback as a great challenge, a problem that Nyerere, Gravenir and Mse (2012) attributed to lack of e-tutor training and low motivation on the part of the e-tutor. Nyerere, Gravenir and Mse (2012) further noted that e-Learning systems in use today in universities in Kenya only employ asynchronous modes of delivery and interaction where most e-tutors upload the course content in form of lecture notes, tests and assignments on the universities' eLearning portals. E-learners in turn download these notes, tests and assignments from the institutions' eLearning portals. They study the lecture notes and attempt the assignments individually because the systems are not designed for collaborative group working. These asynchronous systems are characterised by inadequate interaction, communication and collaboration. According to Gaskell and Mills (2014), one of the performance measures in the online teaching and learning process is e-learners' feedback and e-tutors' feedback. When this feedback is lacking the possible result is e-learner isolation which leads to other problems like high dropout rate, unmet pedagogical needs, and negative perceptions among peers and employers who consider e-Learning as second-rate education.

\subsection{Lack of a Guiding e-Learning Theory(ies)}

Theories play a crucial role in guiding practice across all disciplines. An analysis of the existing e-Learning literature reveals a theoretical gap in e-Learning, what is available are only extensions of the classical learning theories (CLTs) that include the application of ICTs to learning (Mayes and de Freitas, 2004; Kibuku and Orwa, 2018). There is also a lack of a sufficient body of academic literature specially related to e-Learning theory(ies). According to Andrews (2011), Pange and Pange (2011) and Ruth and Kaspar (2017), most of the existing eLearning literature and papers presented in conferences are descriptions of practice (pedagogy), experiences, successes and challenges in e-Learning. As Peraton had remarked earlier in 1981; that "DE had managed very well without a theory", close to four decades later we still don't have one despite the observed growth in DE from early generations to the present-day e-Learning practice (Nichols, 2003, p.1). 
World over, including in Kenya, the CLTs that include behaviorism, cognitivism, and [social] constructivism have been borrowed and applied in the practice of e-Learning under the guise that e-Learning is learning just like conventional learning with the only difference being the ' $\mathrm{e}$ '; where the ' $\mathrm{e}$ ' is argued to be a conduit or a vehicle for delivering learning (Kibuku and Orwa, 2018). Andrews (2011) also argued that e-Learning has been seen to represent just another site for learning; however, a blanket use of CLTs in e-Learning is not fair since conventional learning is different from e-Learning. Serdyukov (2015) underscored the key differences between the two which include: the course structure, content format, content presentation, learning context and processes, instructional tools, e-learner objectives, e-learner perceptions, cognitive learning styles, interaction and communication amongst e-Learning participants, team collaboration, e-learner autonomy, motivation and interest as well as e-learner relations with team members, with the e-tutor, and the society in which he/she exists. Furthermore, these CLTs were stipulated in the $20^{\text {th }}$ Century; long before we had e-Learning with its modern technologies of the $21^{\text {st }}$ Century. Thus there is need for a theory specifically developed to underpin eLearning (Pange and Pange, 2011). Most recently in 2005 the connectivist theory was stipulated to address learning in the $21^{\text {st }}$ Century with its digital technologies (Foroughi, 2015). Unfortunately, connectivism just like the CLTs has certain gaps and shortcomings and as such cannot adequately address all that happens in eLearning. For example, it heavily emphasises technology at the expense of the e-tutor, the e-learner and the learning outcomes (Kibuku and Orwa, 2018). Suffices to say that the application of technology in learning and teaching has always been "technology-led rather than theory-led" (Ravenscroft, 2001, p.134). This was perhaps best captured by Watson (2001, p.252) in a study entitled Pedagogy Before Technology who stated that "the cart has been placed before the horse".

The pedagogical models of e-Learning that have been in use in the delivery of e-Learning include: open learning, learning communities and distributed learning (Dabbagh, 2005). Suffices to say that these e-Learning pedagogical models were designed to match the needs and resources of institutions in the developed countries, which were already enjoying the full benefits of mature ICT infrastructures and technological advancements. To borrow them and try to fit them in the Kenyan context will pose further problems since it is characterised by the afore mentioned challenges of ICT infrastructure, inadequate policy frameworks, limited funding and lack of and/or limited ICT capacity.

\section{Conclusions, Recommendations and Future Research}

From the foregoing review of literature, it is apparent that these challenges inhibit the implementation and provision of e-Learning in Kenya's institutions of higher education and thus influence the full realisation of the benefits and opportunities that can arise from the adoption of e-Learning in the country's higher education sector. However, not all challenges are experienced by all the universities in Kenya and where we have common challenges between universities, the experience is not uniform. That is to say that the degree to which they hinder the implementation and provision of e-Learning varies from one institution to the other. According to the e-Learning Africa (2012) Report; in Kenya, the following challenges to e-Learning rank high in this order: limited bandwidth, lack of appropriate ICT training, lack of priority in ICT funding, ICT sustainability and pressures due to poverty. However, each of the identified challenge presents an improvement area in eLearning and as such need to be addressed. This research recommends that these challenges should be addressed so as to minimize their impact on the implementation and provision of e-Learning in Kenya. National and organisational e-Learning players and researchers need to rise to the occasion and seek ways to address these challenges. The review of these challenges forms the basis upon which further research is underway to solve some of these challenges. This paper is therefore part of an ongoing PhD research; that seeks to establish how the interplay of these problems impacts the implementation and provision of eLearning in Kenya. It is exploring the extent to which lack of a guiding theory in e-Learning may have contributed to [some of] the identified challenges especially the inadequate/lack of learner support, interactivity and collaboration in e-Learning. The research is also seeking to establish the contributions and shortcoming of the CLTs as applied to e-Learning. The main aim of the research is to develop an e-learning theory for interaction and collaboration using the Constructivist Grounded Theory (GT) Methodology proposed by Charmaz (2014), and it is now in the data collection and analysis stage.

\section{Acknowledgements}

This research acknowledges the funding received from National Research Fund (NRF) Kenya and KCA University towards the PhD research. 


\section{References}

Andrews, R. (2011) Does e-Learning Require a New Theory of Learning? Initial Thoughts. Journal of Educational Research Online, [e-journal] 3(1), pp 104-12. Available at: $<$ http://www.j-e-r-o.com/index.php/jero/article/viewFile/84/108> [Accessed 2 April 2019]

Arkorful, A. and Abaidoo, N. (2014) The Role of e-Learning, The Advantages and Disadvantages of Its Adoption in Higher Education. International Journal of Education and Research, [online] 2(12), pp 397-410. Available at <https://www.ijern.com/journal/2014/December-2014/34.pdf > [Accessed 10 March 2019]

Arksey, H. and O'Malley, L. (2005) Scoping Studies: Towards a Methodological Framework. International Journal of Social Research Methodology, [e-journal] 8(1), pp 19-32, Available at: <https://core.ac.uk/download/pdf/56237.pdf> [Accessed 6 April 2019]

Awour, E. and Kaburu, L. G. (2014) e-Learning in Public Institutions in Kenya: Implementation Challenges. Journal of Information Engineering and Applications, [e-journal] 4(4), pp 154-166, Available at: <http://repository.mua.ac.ke/277/1/12448-14771-1-PB.pdf> [Accessed 2 April 2019]

Booth, A. Papaioannou, D. and Sutton, A. (2012) Systematic Approaches to Successful Literature Review. Cornwall, SAGE Publications Inc. [online] Available at: <https://www.researchgate.net/publication/235930866> [Accessed 6 April 2019]

Charmaz, K. (2014) Constructing grounded theory: introducing qualitative methods. Publication Ltd. $2^{\text {nd }}$ Ed. London. SAGE,

Commission of University Education (2017) Universities Authorized to Operate in Kenya, pp 1-2. [online] Available at: <http://www.cue.or.ke/index.php/accredited-campuses-of-universities-in-kenya> [Accessed 7 April2019]

Communications Authority of Kenya (2018) Public Sector ICT Survey Report 2018, pp 1-56, [online] Available at: $<$ https://www.knbs.or.ke/launch-of-the-2016-ict-public-sector-and-enterprise-survey-reports/> [Accessed 8 April2019]

Cuban, L. (2001) Oversold and underused: computers in the classroom. Harvard: University Press, [online] Available at: <http://www.urosario.edu.co/urosario_files/28/28745b9b-7870-4676-9b0e-a84b26278639.pdf> [Accessed 10April2019]

Dabbagh, N. (2005) Pedagogical Models of E-Learning: A Theory-based Design Framework. International Journal of Technology in Teaching and Learning, [e-journal]1(1), pp. 25-44. doi=10.1.1.475.4593

Dijkers, M. (2015) What is Scoping Review? Knowledge Translation for Disability and Rehabilitation Research, [e-journal] 4(1), pp 1-5. Retrieved in April-2019 from: http://ktdrr.org/products/update/v4n1

Farrell, G. (2007) ICTs in Education in Kenya: Survey of ICT and Education in Africa. Kenya Country Report for World Bank, pp 1-14, [online] Available at: <http://www.infodev.org/sites/default/files/resource/InfodevDocuments_354.pdf> [Accessed 10 April 2019]

Foroughi, A. (2015) The Theory of Connectivism: Can It Explain and Guide Learning in the Digital Age? Journal of Higher Education Theory and Practice, [e-journal] 15(5), pp 11-26, Available at: http://www.m.www.nabusinesspress.com/JHETP/ForoughiA Web155.pdf> [Accessed 10 April 2019]

Gaskell, A. and Mills, R. (2014) The Quality and Reputation of Open, Distance and e-Learning: What are the Challenges? The Journal of Open, Distance and E-Learning, [e-journal] 29(3), pp 190-205. doi.org/10.1080/02680513.2014.993603

Government of Kenya (2012) A Policy Framework for Education and Training: Reforming Education and Training in Kenya Sessional Paper. Ministry of Higher Education, Science and Technology, pp 1-133, [online] Available at: <https://www.strathmore.edu/wp-content/uploads/2016/10/sessional_paper_19th_june_nqf.pdf> [Accessed 06 April 2019]

Hadullo, K., Oboko, R. and Omwenga, E. (2017) A Model for Evaluating e-Learning Systems Quality in Higher Education in Developing Countries. International Journal of Education and Development Using Information and Communication Technology, [e-journal] 13(2), pp 185-204. Available at: <https://www.learntechlib.org/p/180643/> [Accessed 10 April 2019]

Hollow, D. (2009) e-Learning in Africa: Challenges, Priorities, and Future Direction. International Conference on Web Engineering, pp 1-10, [online] Available at: <http://www.gg.rhul.ac.uk/ict4d/workingpapers/Hollowe-Learning.pdf> [Accessed 6 April 2019]

Isaacs, S. and Hollow D. (2012) The e-Learning Africa 2012 Report. International Conference on Web Engineering, Germany. pp 1-59 [online] Available at: https://www.gsma.com/mobilefordevelopment/wp-content/uploads/2012/05/The-eLearning-Africa-2012-Report.pdf> [Accessed 6 April 2019]

Kashorda, M and Waema, T. (2014) E-readiness Survey of Kenyan Universities 2013 Report. Kenya Educaion Network, pp 116. [online] Available at: <https://www.kenet.or.ke/sites/default/files/Ereadiness\%202013\%20Survey\%20of\%20Kenyan\%20Universities_Exec\%20Summ.pdf> [Accessed 10 April 2019]

Kenya National Bureau of Statistics (2019) Economic Survey, 2019. KNBS, pp. 147-16. [online] Available at: $<$ https://www.knbs.or.ke/download/economic-survey-2019/> [Accessed 10 April 2019]

Kenya Power and Lighting Company (2017) The Last Mile Connectivity. KPLC, pp 1-28, [online] Available at: <https://www.kplc.co.ke/content/item/1120/last-mile-connectivity> [Accessed 29 March 2019]

Khetan, M. and Gupta V. K. (2013) A Conceptual System Architecture for Cloud-Based e-Learning Systems for Higher Education in India. International Journal of Modern Communication Technologies \& Research, [e-journal] 1(9), pp 1013. Available at: <https://www.erpublication.org/ijmctr/published_paper/IJMCTR011905.pdf> [Accessed 29 March 2019] 
Kibuku, R. N. and Orwa, D. O. (2018) Formulating an e-Learning Theory: A Grounded Theory Approach. In: African Conference for Human Computer Interaction (AfriCHI '18), $2^{\text {nd }}$ Proceedings on Thriving Communities, Windhoek, Namibia. 3-7 December 2018. ACM, New York: USA. doi:10.1145/3283458.3283492

Manro, S., Sighn, J. and Joshi, A. S. (2012) Managing e-Learning Using Clouds : A Cost-Effective Boon in $21^{\text {st }}$ Century. International Journal of Computers \& Distributed Systems, 1(1), pp 11-13.Available at: $<$ https://pdfs.semanticscholar.org/616f/93f94323783de3005e59e188f62950e85711.pdf> [Accessed 29 March 2019]

Mayes, T. and de Freitas, S. (2004) Review of e-Learning Theories, Frameworks and Models. Joint Information Systems Commitee. Published in CURVE Conventory Universities Open Collections, pp 1-44, [online] Available at: <https://researchrepository.murdoch.edu.au/id/eprint/32662/1/review-of-e-Learning-theories.pdf> [Accessed 29 March 2019]

Mutisya, D. N. and Makokha, G. L. (2016) Challenges Affecting Adoption of e-Learning in Public Universities in Kenya. SAGE Journals, [e-journal] 13(3-4), pp 140-157. DOI:10.1177/2042753016672902

Muuro, E. M., Wagacha, P. W., Oboko, R. and Kihoro, J. (2014) Student Percieved Challenges in Online Collaborative Learning Environment: A Case Study of Higher Education Institutions in Nairobi, Kenya. International Review of Research in Open and Distance Learning, [e-journal] 15(6), 133-161.Available at: <http://dx.doi.org/10.19173/irrodl.v15i6.1768>[Accessed 29 March 2019]

Ndungu, M. N., Lewis, C. and Mothobi, O. (2019) The State of ICT in Kenya. Research ICT Africa. After Access. A Policy Paper (No. 9), pp. 1-49, [online] Available at: <https://researchictafrica.net/2019/07/08/after-access-the-state-of-ict-inkenya/> [Accessed 18 September 2019]

Nichols, M. (2003) A Theory for e-Learning. International Forum for Education and Information Technologies, [e-journal] 6(2), 1-10. doi=10.1.1.92.4852

Njenga, J. K. and Fourie, C. H. (2010) The Myths about e-Learning in Higher Education. British Journal of Educational Technology, [e-journal] 42(2), pp 199-212. doi:10.1111/j.1467-8535.2008.00910.x

Njoroge, R. W. and Kibaru, F. (2012) Implementing Quality e-Learning: Which Way for Higher Education Institutions in Kenya? In: EdMedia 2012, World Conference on Educational Multimedia, Hypermedia and Telecommunications 2012. Denver, Colorado, 26-29 June 2012, AACE: USA, [online] Available at: <http://www.academia.edu/download/34439205/E-Learning_HEI_Kenya.pdf> [Accessed 29 March 2019]

Nyerere, J. A., Gravenir, F. Q. and Mse, G. S. (2012) Delivery of Open Distance and e-Learning in Kenya. The International Review of Research in Open and Distance Learning, [e-journal]13(3), pp 185-202. Available at: http://www.irrodl.org/index.php/irrodl/article/view/1120/2203> [Accessed 29 March 2019]

Nyerere, J. (2016) Open and Distance Learning in Kenya. A Baseline Survey Report. Common Wealth Of Learning, pp. 1-23, [online] Available at: <http://oasis.col.org/bitstream/handle/11599/2491/2016_Nyerere_ODL-Kenya.pdf> [Accessed 06 April 2019]

Omwenga, E. I. and Rodrigues, A. (2006) Towards an Education Framework: Synchronous and Asynchronous e-Learning Cases. Journal of the Research Center for Educational Technology, [e-journal] 2(1), pp 46-59. Available at: <http://erepository.uonbi.ac.ke/handle/11295/10431>[Accessed 06 April 2019]

Pange, A. and Pange, J. (2011) Is e-Learning Based on Learning Theories? A literature Review. International Journal of Social, Behaviuoral, Educational, Economic, Business and Industrial Engineering, [e-journal] 5(8), pp 932-936. Available at <https://pdfs.semanticscholar.org/4280/f924a7e578730513a63e104dcea6f27b5b44.pdf> [Accessed 10 April 2019)

Ravenscroft, A. (2001) Designing e-Learning Interaction in the $21^{\text {st }}$ Century. Revisiting and Rethinking the Role of Theory. European Journal of Education, [e-journal] 36(2), pp 133-156. Available at: <http://www.qou.edu/home/sciResearch/pdf/e-LearningResearchs/designingE-Learning.pdf> [Accessed 8 January 2019]

Republic of Kenya (2005) A Policy Framework for Education, Training and Research: Meeting the Challenges of Education Training and Research in Kenya in the $21^{\text {st }}$ Century, Government Printers, [online] Available at: <http://www.knqa.go.ke/wp-content/uploads/2018/10/sessional-paper-sept.-2005-final.pdf> [Accessed 29 March 2019]

Republic of Kenya (2016) Universities Act 2012 (Rev. 2016), [online] Available at: <http://www.knqa.go.ke/wpcontent/uploads/2018/10/Universities-Act-42-of-2012.pdf> [Accessed 29 March 2019]

Republic of Kenya (2016) The Draft National ICT Policy 2016. Ministry of Information and Communication Technology, [online] Available at: <http://icta.go.ke/pdf/National-ICT-Policy-20June2016.pdf> [Accessed 29 March 2019]

Republic of Kenya (2019) Digital Economy Blueprint. Powering Kenya's Transformation. Ministry of Information, Communications and Technology, pp. 1-96, [online] Available at: <http://www.ict.go.ke/wpcontent/uploads/2019/05/Kenya-Digital-Economy-2019.pdf> [Accessed 18 September 2019]

Ruth, M. and Kaspar, K. (2017) The e-Learning Setting Circle: First Steps towards Theory Development in e-Learning Research. The Electronic Journal of E-Learning, [e-journal] 15(1), pp 94-103. Available at: <from www.ejel.org.> [Accessed 3 April 2018]

Sabi, H. M. (2014) Opportunities and Challenges for Adopting Cloud Computing at Universities in Developing Countries. In: ICT for Africa, $6^{\text {th }}$ Annual International Conference on Harnessing ICT in Education for Global Competitiveness. Yaounde, Cameroon, 1-4 October 2014, [online] Available at: <https://www.researchgate.net/profile/Humphrey_Sabi/publication/273951114.pdf> [Accessed 6 April 2019] 
Serdyukov, P. (2015) Does Online Education Need a Special Pedagogy? Journal of Computing and Information Technology, [e-journal] 23(1), pp 61-74. DOI:10.2498/cit.1002511.

Shank, P. (2015) Thinking Critically to Move e-Learning Forward. In: S. Carliner and P. Shank, eds, 2008. The e-Learning handbook: past promises, present challenges. Learning Peaks LLC. pp 1-13, [online] Available at: <https://www.researchgate.net/profile/Patti_Shank> [Accessed 10 April 2019]

Ssekakubo, G., Suleman, H. and Marsden, G. (2011) Issues of Adoption: Have e-Learning Management Systems Fulfilled their Potential in Developing Countries? In: South African Institute of Computer Scientists and Information Technologists, Conference on Knowledge, Innovation and Leadership in a Diverse, Multidisciplinary Environment. CT, SA, 3-5 October 2011. ACM, New York: USA. [online] DOI: 10.1145/2072221.2072248

Stepanyan, K., Littlejohn, A. and Margaryan, A. (2013) Sustainable e-Learning: Towards a Coherent Body of Knowledge. Educational Technologies \& Society, [e-journal] 16(2), pp 91-102. Available at: <https://pdfs.semanticscholar.org/5a78/1648c4b06917c4a33d3678fd1a490859f1e3.pdf> [Accessed 8 January 2019]

Tarus, J. K., Gichoya, D. and Muumbo, A. (2015) Challenges of Implementing e-Learning in Kenya: A Case of Kenyan Public Universities. International Review of Research in Open and Distance Learning, [e-journal] 16(1), pp 120-140. DOI:10.19173/irrodl.v16i1.1816.

Tarus, J. K. and Gichoya, D. (2015) e-Learning in Kenyan Universities: Preconditions for Successful Implementation. Electronic Journal of Information Systems in Developing Countries, [e-journal] 66(4), pp 1-14. doi=10.1.1.662.1844

Wambugu, L. and Kyalo, D. (2013) Open and Distance Education as a Strategy of Improving Higher Education in the $21^{\text {st }}$ Century in Kenya- A Case Study of Univerty of Nairobi. Journal of Education Practice. [e-journal] 4(14), pp 25-29. Available at: < https://s3.amazonaws.com/academia.edu.documents/31667525> [Accessed 14 November 2-19]

Watson, D. M. (2001) Pedagogy Before Technology. Rethinking the Relationship between ICT and Teaching. International Forum for Education and Information Technologies, [e-journal] 6(4), pp 251-266. doi=10.1.1.502.2231

Wright, C. R., Ghanarajan, G. and Reju S. A. (2009) Recurring Issues Encountered by Distance Educators in Developing and Emerging Nations. The International Review of Research in Open and Distance Learning, [e-journal] 10(1), pp 1-25. Available at < http://www.irrodl.org/index.php/irrodl/article/view/608/0> [Accessed 8 January 2019]

Wu, J., Tennyson, R. D. and Hsia, T. (2010) A Study of Student Satisfaction in Blended e-Learning System Environment. Computer and Education, Elsevier, [e-journal] 55(2010), pp 155-164. doi:10.1016/j.compedu.2009.12.012 


\section{Appendix I: Literature Review Materials}

\begin{tabular}{|c|c|}
\hline Key Word(s) & Title of Reviewed Material \\
\hline \multirow[t]{5}{*}{ e-Learning in Kenya } & Towards an Education Framework: Synchronous and Asynchronous e-Learning Cases \\
\hline & $\begin{array}{l}\text { ICTs in Education in Kenya: Survey of ICT and Education in Africa. Kenya Country Report for } \\
\text { World Bank }\end{array}$ \\
\hline & The e-Learning Africa 2012 Report. \\
\hline & $\begin{array}{l}\text { Open and Distance Education as a Strategy of Improving Higher Education in the } 21^{\text {st }} \text { Century } \\
\text { in Kenya - A Case Study of University of Nairobi }\end{array}$ \\
\hline & Open and Distance Learning in Kenya. A Baseline Survey Report. Common Wealth Of Learning \\
\hline \multirow{5}{*}{$\begin{array}{l}\text { e-Learning, } \\
\text { Opportunities, Benefits, } \\
\text { Advantages, Success, } \\
\text { Challenges, } \\
\text { Disadvantages and } \\
\text { Failures in Kenya } \\
\end{array}$} & e-Learning in Public Institutions in Kenya: Implementation Challenges \\
\hline & Challenges Affecting Adoption of e-Learning in Public Universities in Kenya \\
\hline & Challenges of Implementing e-Learning in Kenya: A Case of Kenyan Public Universities \\
\hline & e-Learning in Kenyan Universities: Preconditions for Successful Implementation. \\
\hline & The Role of e-Learning, the Advantages and Disadvantages of its Adoption in Higher Education \\
\hline \multirow{7}{*}{$\begin{array}{l}\text { e-Learning, } \\
\text { Opportunities, Benefits, } \\
\text { Advantages, } \\
\text { Successes, Challenges, } \\
\text { Disadvantages and } \\
\text { Failures in Developing } \\
\text { Countries }\end{array}$} & Recurring Issues Encountered by Distance Educators in Developing and Emerging Nations \\
\hline & $\begin{array}{l}\text { Issues of Adoption: Have e-Learning Management Systems Fulfilled their Potential in } \\
\text { Developing Countries? }\end{array}$ \\
\hline & e-Learning in Africa: Challenges, Priorities, and Future Direction \\
\hline & $\begin{array}{l}\text { A Conceptual System Architecture for Cloud-Based e-Learning Systems for Higher Education in } \\
\text { India }\end{array}$ \\
\hline & Managing e-Learning Using Clouds : A Cost-Effective Boon in $21^{\text {st }}$ Century \\
\hline & $\begin{array}{l}\text { Opportunities and Challenges for Adopting Cloud Computing at Universities in Developing } \\
\text { Countries }\end{array}$ \\
\hline & Sustainable e-Learning: Towards a Coherent Body of Knowledge \\
\hline \multirow{4}{*}{$\begin{array}{l}\text { e-Learning Pedagogical } \\
\text { Issues in Kenya }\end{array}$} & Pedagogical Models of E-Learning \\
\hline & Delivery of Open Distance and e-Learning in Kenya \\
\hline & Does Online Education Need a Special Pedagogy? \\
\hline & Pedagogy Before Technology. Rethinking the Relationship between ICT and Teaching \\
\hline \multirow{8}{*}{$\begin{array}{l}\text { e-Learning Theoretical } \\
\text { Issues }\end{array}$} & Does e-Learning Require a New Theory of Learning? Initial Thoughts. \\
\hline & The Theory of Connectivism: Can It Explain and Guide Learning in the Digital Age? \\
\hline & Formulating an e-Learning Theory: A Grounded Theory Approach \\
\hline & Review of e-Learning Theories, Frameworks and Models. \\
\hline & A Theory for e-Learning \\
\hline & Is e-Learning Based on Learning Theories? \\
\hline & $\begin{array}{l}\text { Designing e-Learning Interaction in the } 21^{\text {st }} \text { Century. Revisiting and Rethinking the Role of } \\
\text { Theory. }\end{array}$ \\
\hline & $\begin{array}{l}\text { The e-Learning Setting Circle: First Steps towards Theory Development in E-Learning } \\
\text { Research }\end{array}$ \\
\hline \multirow{4}{*}{$\begin{array}{l}\text { ICT and e-Learning } \\
\text { policy in Kenya }\end{array}$} & A Policy Framework for Education and Training \\
\hline & $\begin{array}{l}\text { A Policy Framework for Education, Training and Research: Meeting the Challenges of } \\
\text { Education Training and Research in Kenya in the } 21^{\text {st }} \text { Century }\end{array}$ \\
\hline & Universities Act 2012 Rev 2015/16 \\
\hline & The Draft National ICT Policy 2016 \\
\hline \multirow{6}{*}{$\begin{array}{l}\text { Kenyan ICT } \\
\text { Infrastructure }\end{array}$} & Public Sector ICT Survey Report 2018 \\
\hline & E-readiness Survey of Kenyan Universities 2013 Report \\
\hline & Economic Survey 2019 \\
\hline & The Last Mile Connectivity \\
\hline & The State of ICT in Kenya. Research ICT Africa. After Access. \\
\hline & Digital Economy Blueprint. Powering Kenya’s Transformation \\
\hline \multirow{4}{*}{$\begin{array}{l}\text { Quality Assurance in e- } \\
\text { Learning in Kenya }\end{array}$} & Universities Authorized to Operate in Kenya \\
\hline & The Quality and Reputation of Open, Distance and e-Learning: What are the Challenges? \\
\hline & $\begin{array}{l}\text { A Model for Evaluating e-Learning Systems Quality in Higher Education in Developing } \\
\text { Countries }\end{array}$ \\
\hline & Implementing Quality e-Learning: Which Way for Higher Education Institutions in Kenya? \\
\hline \multirow{3}{*}{$\begin{array}{l}\text { Technology Issues in e- } \\
\text { Learning in Kenya }\end{array}$} & The Myths about e-Learning in Higher Education \\
\hline & The e-Learning Handbook: Past Promises, Present Challenges \\
\hline & Oversold and Underused: Computers in the Classroom. \\
\hline \multirow{2}{*}{$\begin{array}{l}\text { e-Learning Support and } \\
\text { Collaboration }\end{array}$} & A Study of Student Satisfaction in Blended e-Learning System Environment. \\
\hline & $\begin{array}{l}\text { Student Percieved Challenges in Online Collaborative Learning Environment: A Case Study of } \\
\text { Higher Education Institutions in Nairobi, Kenya. }\end{array}$ \\
\hline
\end{tabular}

